\title{
REINTERPRETASI KONSEP Fî SABÎL AL-LÂH SEBAGAI ASHNÂF ZAKAT
}

\author{
Ani Wafiroh*
}

\section{Abstract}

The term jihad fi sabill al-Lâh is often used to refer to physical war in the path of God. The word, as it is derived from the Qs. al-Tawbah (9): 60, in fact connotes specific and general meanings. The specific meaning of it commonly found in classical ulema's interpretation is related to the war. This interpretation is based on historical evidence and supported by the literal meaning of Qur'an and the hadith. But such a meaning is now criticized and regarded as going beyond the conceptual boundary of jihad in Islam.

This article seeks to explore the general meaning of the term in the works of classical and contemporary Muslim scholars, aimed at offering a more contextual meaning. It shows that the term does not always necessarily mean the physical war in the name of God or religion, but it can be meant as education, human welfare, and social development.

Keywords: Zakat, Jihâd, Fî̀ Sabîl al-Lâh, Peperangan, Dakwah Islamiyah, Mashâlih al-Muslimîn.

PEMBAHASAN tentang jühâd fî̀ sabîl al-Lâh nyaris selalu diidentikan dengan peperangan, pertumpahan darah, dan pertempuran yang terjadi antara orang muslim dengan nonmuslim. Hal ini tidak sepenuhnya salah, karena didukung oleh makna tekstual al-Qur'an maupun hadis. Namun,

*Penulis adalah dosen DPK IAIN Mataram di Poltekes Mataram, Jln. Kesehatan V/10 Mataram, email: anwaf_mus@yahoo.co.id. 
pemahaman semacam itu berimplikasi buruk bagi Islam sehingga seakan Islam disebarkan dengan pedang.

Dalam konteks (jïhâd) fî̀ sabîl al-Lâh sebagai amil zakat terjadi dualisme dalam khazanah pemikiran Islam; ada yang mengatakan bahwa hanya jihad dalam pengertian peperangan, namun ada juga yang berpendapat pada semua jenis perbuatan baik. ${ }^{1}$ Pemahaman jihad kepada makna yang pertama, telah "menggiring" konsep ashnâf fî̀ sabîl al-Lâh menjadi sangat terbatas, bahkan dalam kitab Bughyat al-Mustarsyidin fî Talkhîs alFatâwâ dikatakan:

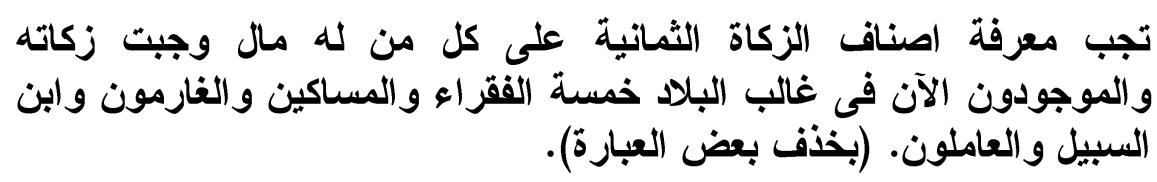

Artinya: "Wajib mengetahui golongan-golongan orang yang menerima zakat, yaitu delapan ashnâf bagi orang yang memiliki harta yang wajib dizakatkan, namun di beberapa negara hanya ada lima ashnâf saja, yakni fakîr, miskîn, ghârimîn, ibn sabîl, dan âmil zakat'. ${ }^{2}$

Dengan demikian, ashnâf mu'allâf dan fì sabîl al-Lâh dianggap tidak ada lagi oleh sebagian ulama. Penghilangan ashnâf fî sabîl alLâb kelihatannya disebabkan karena fî̀ sabîl al-Lâh dimaknai secara tekstual kepada orang yang ikut berperang secara fisik (ghuгzât) saja. Tentu saja hal ini sangat bertentangan dengan pendapat sebagian ulama lainnya yang berusaha memaknai ashnâf

${ }^{1} \mathrm{Hal}$ ini agak berbeda dengan masalah sumber zakat. Dalam masalah ini terjadi dualisme antara kenyataan di lapangan yang dimotori oleh sebagian ulama yang berbasis pondok salafi dengan Departemen Agama yang dimotori oleh para akademisi. Sebagian ulama tradisional tetap pada pendirian bahwa zakat itu wajib dikeluarkan tetapi dengan syarat-syarat yang sangat ketat, seperti harus mengenyangkan, makanan pokok, tahan lama, kering, dan sebagainya. Sementara Depag cukup dengan mensyaratkan komoditi yang bernilai ekonomis.

${ }^{2}$ Muhammad al-Mahsyat, Bugyat al-Mustarsyidîn (ttp. Mahfûzah lî alNasyrî, tt.), 105. 
fî̀ sabîl al-Lâh secara lebih luas, sehingga mencakup segala perbuatan baik yang mengarah kepada syi'ar Islam. Namun, dalam prakteknya, para wajib zakat, terutama di pedesaan, menyerahkan zakatnya tidak kepada kelompok delapan (al-ashnâf al-tsamâniyyah), melainkan kepada pemimpin agama setempat. Padahal pemimpin agama tersebut sebetulnya tidak bertindak sebagai âmil tetapi sebagai mustahiq (orang yang berhak menerima zakat) dalam katagori sabîl al-Lâh. ${ }^{3}$

Sikap seperti di atas, menurut Ali, tidak sepenuhnya salah, namun sikap seperti itu seyogyanya ditinggalkan, untuk menghindari penumpukan harta (zakat) pada orang tertentu, padahal salah satu tujuan zakat adalah pemerataan rejeki. ${ }^{4} \mathrm{Hal}$ itu juga menunjukkan penempatan skala prioritas yang kurang tepat, di mana fî sabîl al-Lâh yang lain seperti pembangunan masjid dan madrasah menjadi dinomorduakan. ${ }^{5}$

Dengan memahami konsep kemaslahatan ummat, maka penafsiran makna fî̀ sabîl al-Lâh yang dimaknai sebagai bentuk jihad dalam pengertian peperangan kurang bisa menyelesaikan masalah dalam konteks sekarang ini. Sebab peperangan dalam pengertian secara langsung berada di medan pertempuran, sesungguhnya memiliki tujuan untuk menegakkan kebenaran dan syi'ar Islam. Ketika syi'ar Islam itu dapat ditegakkan dengan cara-cara di luar peperangan, mestinya harus dipandang sebagai jihad fî̀ sabîl al-Lâh juga, karena memiliki maksud dan tujuan yang sama, yakni syi'ar Islam.

${ }^{3}$ Dengan alasan termasuk ashnâf fî̀ sabîl al-Lâh, misalnya, banyak tuan guru dalam kapasitasnya sebagai ulama di Lombok menerima zakat mâl atau zakat fithrah. niknya, distribusi kepada tuan guru ini biasanya sangat diprioritaskan, walaupun pada umumnya mereka sangat kaya.

${ }^{4}$ Mohammad Daud Ali, Sistem Ekonomi Islam, Zakat, dan Wakaf (Jakarta: UI-Press, 1998), 56.

${ }^{5}$ Gejala memberikan prioritas kepada ulama ini dipengaruhi oleh dua hal, yakni doktrin dalam kitab figh terutama pendapat ulama yang memaknai fì sabîl al-Lâh secara luas, dan penghargaan yang tinggi kepada guru sebagaimana yang diajarkan pada kitab Ta'lim al-Muta'allim karangan alJurjânî. 
Atas dasar itu, tulisan ini berupaya untuk menggali khazanah pemikiran ulama seputar makna fî sabîl al-Lâh dalam penggunaannya di seputar distribusi zakat, khususnya yang berkenaan dengan ashnâf yang ke tujuh, yakni ashnâf fî sabîl alLâh, sebagaimana tercantum dalam Qs. al-Tawbah (9): 60. Pertanyaan mengapa makna fî̀ sabîl al-Lâh digunakan dalam distribusi zakat khususnya pada ashnâf yang ke tujuh, perlu mendapatkan perhatian secara khusus. Hal ini disebabkan karena luasnya makna jihad itu sendiri, sementara ada ulama yang memaknainya secara rigid. Tulisan ini diharapkan mampu merumuskan argumentasi yang jelas dan konstruktif bagi pemaknaan jühâd fî sabîl al-Lâh dalam konteks kekinian sehingga Islam benar-benar dapat tampil di semua lini (shâlibun li kulli zamân wa makân).

\section{Makna Tekstual dan Kontekstual Jihâd dan Fî Sabîl al-Lâh}

Dalam memahami makna jïhâd dan fî̀ sabîl al-Lâh ini, perlu ditelusuri dari dua perspektif, yakni tekstual dan kontekstual (umum). Pemaknaan dengan menggunakan dua pendekatan ini sangat penting agar dapat menghasilkan sebuah konklusi yang lebih populis bagi perjuangan menegakkan syi'ar Islam. Kata jihad sebenarnya tidak harus dimaknai kepada perang. Jihad bisa saja dimaknai secara luas kepada segala usaha yang dilakukukan secara sungguh-sungguh, sedangkan term fî̀ sabîl al-Lâh, sering d"dikawinkan" dengan kata ini sehingga menjadi jïhâd fî sabîl alLâh, ${ }^{6}$ sehingga mayoritas ulama memaknai fî sabîl al-Lâh sebagai

'Penggunaan kata jühâd dan fî̀ sabîl al-Lâh dalam satu idiom ('ibârah ishthilâhiyyah) dapat ditemukan di berbagai ayat dan hadis, di antaranya: Qs. al-Nisầ (4): 95 dengan lafal "al-mujâhidûn fi sabîl al-Lâh”, al-Tawbah (9): 19 dengan lafal "wajâhada fî sabîl al-Lâb”, al-Hujurât (49): 15 dengan "wajâhidû bi amwâlikum wa anfusikum fî sabîl al-Lâh", al-Shâff (27): 11 dengan lafal "watujâbidûn fî sabîl al-Lâh". Sedangkan dalam hadis ditemukan dalam hadis Bukhârî Muslim yang artinya: "apakah perbuatan yang paling dicintai Allah? Nabi 
kepada peperangan (ghaz̧w atau jihâd). Berikut ini akan dikemukakan makna kedua istilah tersebut menurut makna tekstual dan kontekstualnya.

Makna tekstual, makna tekstual ini dapat dilihat secara etimologis dan terminologis. Secara etimologi, jihâd berasal dari kata jahada-yajhadu-jubdan yang artinya berusaha dengan sungguhsungguh. Jâhada fî sabîl al-Lâh berarti berjuang, berjihad, berperang di jalan Allah. Sedangkan bentuk masdarnya jihâd, berarti perjuangan, sehingga jỉhâdun fî̀ sabîl al-Lâh berarti perjuangan di jalan Allah. Kata jahada dimaknai dengan jahada fî al-amr atau jadda (berusaha dengan sungguh-sungguh), sedangkan jâhada (bab fấala) dimaknai dengan badz̧ala wu'abu (mencurahkan segala kemampuan). ${ }^{7}$ Secara terminologi, jïhâd artinya meluangkan segala usaha dan berupaya sekuat tenaga serta menanggung segala kesulitan di dalam memerangi musuh dan menahan agresinya. ${ }^{8}$ Zainuddin Al-Malibary memaknai $f \hat{\imath}$ sabîl al-Lâh sebagai pejuang agama yang dilakukan secara sukarela tanpa mengharapkan ganjaran di dunia. Mereka ini harus diberikan alat perang, pakaian, biaya dan nafkah, bahkan keluarga yang ditinggalkannya harus diberikan nafkah. ${ }^{9}$ Abdurrahman Mahmud menyebut istilah fî̀ sabîl al-Lâh yang terdapat dalam Qs. al-Tawbah (9): 60, dengan istilah al-guzzât, yakni orang yang membiasakan diri dalam berjuang atau berperang walaupun harus menggunakan harta mereka sendiri (bum man tathawwaûw bî al-jïhâd walau ma'a ghinâhum). ${ }^{10}$

menjawab: sholat tepat waktu. Kemudian apa lagi? Nabi menjawab: birrul wâlidain. Kemudian apa lagi? Nabi menjawab: al-jỉhâdu fî sabîl al-Lâb”".

${ }^{7}$ Ahmad Warson Al-Munawwir, Al-Munawwir: Kamus Arab Indonesia (Yogyakarta: ttp., 1984), 234. 27.

${ }^{8}$ Sayyid Sabiq, Fiqh Sunnah, jilid III (Libanon: Dâr Fikr, 1403H/1983M),

9Zainuddin Bin Abdul Aziz Al-Malibariy, Fath al-Mu'în, jilid II, ter. M. Aliy As'ad (Kudus: Menara Kudus, 1979), 40.

${ }^{10}$ Abdurrahman Mahmud, al-Nafakhât al-Shamâdiyyah, jilid I dan II (Mesir: al-Madani, tt.), 317. 
Lembaga Ulama-ulama Besar Saudi Arabia yang bergabung dalam Lajnah al-Dâ'imah li al-Bubûts al-'Imiyyah wa al-Iftâ', pada pertemuan kelima yang diadakan di kota al-Thaif antara tanggal 5-8-1394 H sampai tanggal 22-8-1394 H untuk membahas firman Allah mengenai alokasi zakat fì sabîl al-Lâh. Setelah melalui penelitian dan penelaahan atas berbagai pendapat ulama, mereka memutuskan bahwa yang dimaksud dengan fî̀ sabîl alLâh, adalah orang-orang yang berjihad secara sukarela dan membutuhkan berbagai fasilitas selama mereka berperang. Apabila mereka tidak ada, baru bisa dialokasikan kepada golongan-golongan lain yang berhak menerima zakat. Namun, tidak boleh disumbangkan untuk penyediaan fasilitas umum, kecuali bila sudah tidak ada lagi kaum miskin serta berbagai golongan yang disebutkan dalam al-Qur'an. ${ }^{11}$

Dengan demikian, Lembaga Ulama-ulama Besar Saudi Arabia di atas menyepakati, bahwa makna fî sabîl al-Lâh hanya pada jihâd (perang) fî̀ sabîl al-Lâh saja dan tidak membenarkan pengembangan makna fî̀ sabîl al-Lâh kepada kemaslahatan umum.

Makna kontekstual. Q. Shaleh berpendapat, bahwa fì sabîl alLâh adalah orang-orang yang melaksanakan jihad di jalan Allah. Akan tetapi menurut ahli fiqh, yang termasuk fî̀ sabîl al-Lâh di samping jihad, ialah menyediakan segala fasilitas yang dianggap baik menurut tuntunan agama seperti memakmurkan masjid, madrasah, rumah yatim, rumah sakit, kafan kafan untuk mayat yang tidak mampu. ${ }^{12}$ Sayyid Sabiq menjelaskan makna kontekstual fî̀ sabîl al-Lâh sebagai metode untuk mendorong orang untuk mencapai ridha Allah baik berupa ilmu atau amal perbuatan. ${ }^{13}$ Abu Hanifah, Malik, dan Syafi'i berpendapat,

11'Abd al-Lâh al-Muslihh dan Shalah al-Shâwî, Mâ Lâ Yasa' al-Tâjï Jahluh, ter. Abu Umar Basyir (Jakarta: Dar al-Haq, 2004), 481-82.

${ }^{12}$ Q. Shaleh, dkk., Ayat-Ayat Hukum: Tafsir dan Uraian Perintah-Perintah dalam Al-Qur'an (Bandung: Diponegoro, 1976), 184.

${ }^{13}$ Sabiq, Fiqh..., Jilid II, 333. 
bahwa alokasi zakat fî sabîl al-Lâh yang tersebut dalam firman Allah Qs. al-Tawbah (9): 60, dikhususkan kepada orang yang berperang yang tidak mendapatkan gaji dari pemerintah. ${ }^{14}$ Hasan, Ahmad, dan Ishaq berpendapat bahwa melaksanakan ibadah haji termasuk fî sabîl al-Lâh sehingga mereka berhak atas alokasi zakat. Sementara itu, al-Marâghî menjelaskan makna kontekstual dari kata fî sabîl al-Lâh dengan mengatakan:

والدق أن المراد بسبيل الله مصالح المسلمين العامة التى بها قوام امر الدين

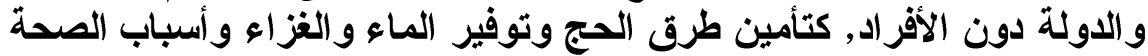

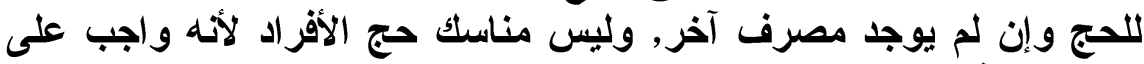

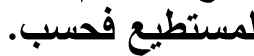

Artinya: "Sebenarnya, yang dimaksud dengan fì sabîl al-Lâh adalah kemaslahatan umat muslim secara umum yang mengayomi urusan agama dan negara, bukan untuk kepentingan pribadi, seperti menjamin terselenggaranya ibadah haji, membagikan air, peperangan, dan hal-hal yang mendorong terjaganya kesehatan dalam menunaikan haji, jika tidak ada biaya dari anggaran yang lain. Sementara kewajiban melaksanakan haji bagi setiap individu tidak boleh diberikan dari zakat karena haji wajib hanya bagi orang yang mampu". 15

Senada dengan al-Marâghî, al-Qâsimî menjelaskan pendapat para ulama yang memaknai kata fì sabîl al-Lâh secara kontekstual.

قال الرازى: لا يوجب قوله (فى سبيل الله) القصر على الغزاة. ولذا قال القفال

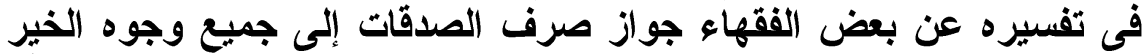

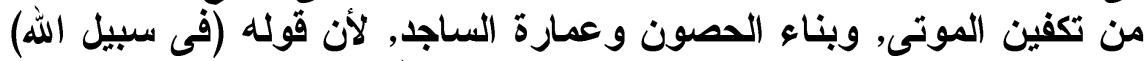

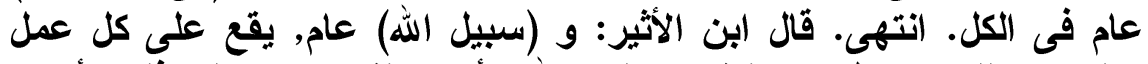

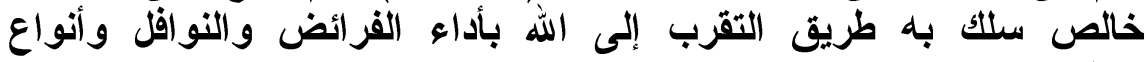

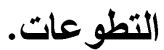

${ }^{14}$ Muhammad 'Alî al-Sâyis, Tafsîr Âyât al-A blkâm (Mesir: Matba'ah Muhammad 'Ali Shabih $\underline{\text {, tt.), } 41 .}$

${ }^{15} \mathrm{~A}$ hmmad Mushthafâ al-Marâghî, Tafsîr Al-Marâghtî, jilid IV (Mesir: Mushthafâ al-Bâb al-ㅂalabî, 1389 H/1969 M), 145. 
Artinya: "Berkata al-Razy pada kata fî sabîl al-Lâh, tidak wajib membatasi kepada peperangan. Oleh karena itu, Imam Quffâl menulis dalam tafsirnya, bahwa sebagian ulama fikih membolehkan mendistribusikan zakat kepada semua jenis perbuatan baik, di antaranya mengkafani mayat, membangun benteng pertahanan, dan memakmurkan masjid. Hal ini dikarenakan kata wa fî sabîl alLâh bersifat umum yang mengacu kepada semua persoalan yang baik. Ibnu Atsir juga berkata: kata sabîl al-Lâh bersifat umum, berlaku kepada setiap pekerjaan yang dilakukan secara sukarela untuk mendekatkan diri kepada-Nya dengan melakukan perbuatan wajib maupun perbuatan sunnat dan sejumlah perbuatan yang dianjurkan". ${ }^{16}$

Dari dua kutipan di atas, mengindikasikan makna fî sabîl alLâh dapat diperluas kepada segala sesuatu yang berdampak dan bernilai positif bagi kepentingan umum (mashâlih al-ummat). Hal ini dimungkinkan karena perjuangan dakwah Islamiyah itu tidak selalu dalam pengertian berperang secara fisik tetapi juga berperang terhadap kebodohan dan keterbelakangan umat Islam, sesungguhnya merupakan bagian dari jihad itu sendiri. Beberapa data dan informasi dari Rasulullah saw. yang mengindikasikan kepada pemaknaan jihhâd dan fî̀ sabîl al-Lâh pada makna umum, di antaranya: pertama, hadis riwayat Bukhârî dari Aisyah ra.:

\section{قالت: استأذنت النبى صلى الله و سلم في الجهاد فقال: جهادكن الحج.}

Artinya: "Aku berkata: aku telah meminta ijin Nabi saw. untuk berjihad. Beliau berkata: jihadnya kalian adalah haji" ${ }^{17}$

Dalam riwayat yang lain:

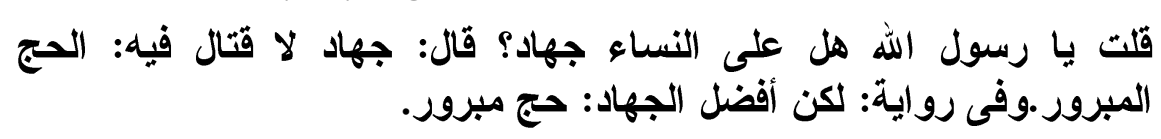

16Muhammad Jamâl al-Dîn al-Qâsimi, Mahâsin al-Ta'wil (Beirut: Dâr Ihya al-Kutub al-'Arabiyyah, 1376H./1957M.), 2181

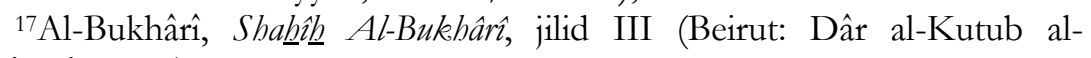
'Ilmiyyah, 1992), 299-300. 
Artinya: “Aku berkata: 'Wahai Rasulullah, Adakah kewajiban jihad bagi perempuan? Nabi Bersabda: jihad yang tidak ada pembunuhan yaitu haji mabrur. Dalam riwayat lain: Tetapi sebaik-baiknya jihad adalah haji mabrur". ${ }^{18}$

Kedua, hadis riwayat Nasâ'î dari Ibn 'Umar ra.:

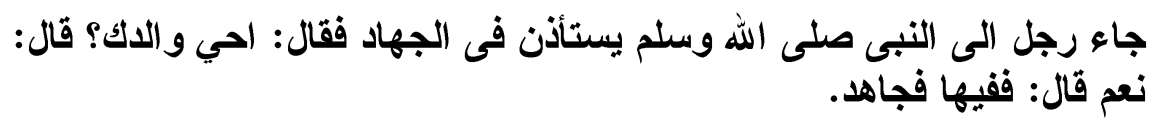

Artinya: "Seorang laki-laki datang kepada Rasulullah meminta izin berjihad. Rasulullah kemudian bersabda: "adakah kedua orang tuamu masih hidup? Orang tersebut menjawab:"ya”. Rasulullah selanjutnya bersabda: membantu orang tuamu itu adalah berjuang". 19

Sabiq menjelaskan dalam Syir'ah al-Islâm, bahwa tidak perbolehkan untuk berjihad, kecuali orang yang memiliki waktu yang luang untuk keluarganya serta menghargai atau memuliakan kedua orang tuanya. Hal ini, harus diprioritaskan terlebih dahulu daripada jihad—dalam pengertian perang—bahkan ini merupakan bentuk jihad yang paling utama. ${ }^{20}$

Dari penjelasan di atas, Nabi Muhammad saw. telah mengembangkan makna fì sabîl al-Lâh bahkan jỉhâd bukan hanya peperangan secara fisik, melainkan juga peperangan dalam bentuk non fisik, yang memiliki tujuan dan sunstansi yang sama, yakni dalam rangka menjaga syi'ar Islam dan kepentingan umum. Secara historis, perintah untuk melakukan jihad terjadi pada tahun kedua hijriyyah dengan turunnya Qs. al-Baqarah (2): 216:

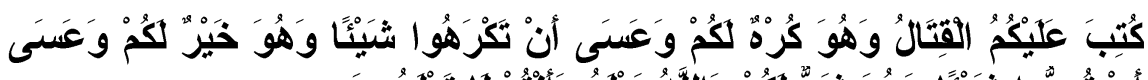

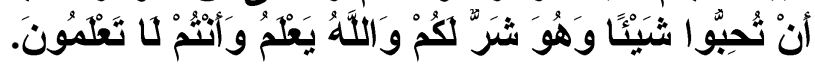

18al-Shan'ânî, Subul al-Salàm (Beirut: Dâr al-Kutub al-'Ilmiyyah, 1988), 76.

19Jalâl al-Dîn al-Suyûthî, Sunan al-Nasâ'î, jilid III (Beirut: Dâr al-Ma'rifah, tt), 3103. al-Shan'ânî, Subul ..., 77.

20Sabiq, Fiqh ..., 34. 
Artinya: "Diwajibkan atas kamu berperang, padahal berperang itu adalah sesuatu yang kamu benci. Boleh jadi kamu membenci sesuatu, padahal ia amat baik bagimu, dan boleh jadi kamu menyukai sesuatu, padahal ia amat buruk bagimu; Allah mengetahui, sedang kamu tidak mengetahui". 21

Hal ini menunjukkan bahwa diwajibkan jihad pada saat itu disebabkan karena dakwah dengan jalan persuasif sudah tidak dimungkinkan lagi. Oleh karena itu, jihad pada dasarnya bukan merupakan kewajiban yang berlaku bagi setiap individu muslim melainkan fardlu kifâyah. Namun, jihad dapat berubah menjadi fardlu 'ain apabila; (1) seorang yang sudah matang (cukup umur dan berakal [mukallaf]) berada di tengah-tengah pasukan yang berperang sesuai dengan firman Allah Qs. al-Anfâl (8): 45; (2) musuh mendatangi tempat atau negara kaum muslimin, dan (3) apabila hakim menugaskan seorang mukallaf. Jihad hukumnya wajib bagi setiap muslim laki-laki yang berakal, baligh, tidak cacat fisik dan memiliki materi yang cukup untuk bekal hidupnya, maupun keluarganya sehingga ia bisa dengan bebas melakukan jihad. ${ }^{22}$

Berdasarkan fakta sejarah di atas, Sabiq menjelaskan bahwa lafaz fî sabîl al-Lâh berorientasi untuk kepentingan diri pribadi, agama, dan negara (self, religion, and state oriented). Akan tetapi, jika dalam keadaan perang, maka yang harus diutamakan adalah mempersiapkan segala fasilitas atau kebutuhan untuk menghadapi peperangan, dengan membeli alat-alat perang, melatih pasukan, membeli alat-alat perang, meyiapkan perlengkapan pasukan perang, dan membangun rumah sakit khusus untuk orang-orang yang ikut berperang (tentara), sedangkan untuk kepentingan umum dengan memperbaiki jalan, benteng dan lain-lain. ${ }^{23}$ Secara lebih khusus, Sabiq mengilustrasikan pengembangan makna fî sabîl al-Lâh dengan konteks modern sekarang sebagai berikut:

${ }^{21}$ Qs. al-Baqarah (2): 216.

22 Sabiq, Fiqh..., jilid III, 29-31.

23Ibid., I, 333. 


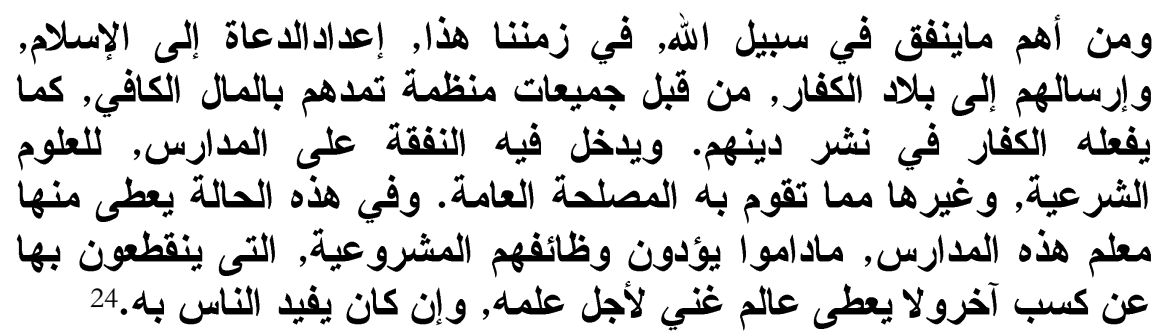

Artinya: "Dan salah satu yang mendesak pada konteks sekarang adalah menyiapkan tenaga-tenaga da'i yang akan mengajak kepada Islam, dan mengirim mereka ke negara nonmuslim. Kegiatan ini dikelola oleh organisasi-organisasi profesional yang akan menyiapkan dana yang cukup, seperti yang dilakukan oleh orang-orang nonmuslim dalam menyebarkan agama mereka. Dan termasuk dalam makna $\mathrm{f} \hat{\imath}$ sabîl al-Lâh, yakni menyumbangkan harta untuk sekolahsekolah-yang mengajarkan ilmu syari'at—dan lain sebagainya demi kepentingan umum. Dalam konteks ini, para pengajar harus diberikan zakat selama mereka menunaikan tugas yang sudah dibebankan kepadanya. Hal ini akan mencegah mereka untuk mencari penghasilan di tempat lain. Zakat tidak diperbolehkan untuk diberikan pengajar yang mendapatkan harta dikarenakan ilmunya, sekalipun orang-orang mendapatkan manfaat karena otoritas keilmuannya".

Apa yang dikemukakan Sabiq di atas seolah membantah secara tegas pemaknaan kaku terhadap jïhâd dan fì sabîl al-Lâh, yang selama ini dipegang oleh mayoritas ulama.

\section{Pemaknaan Jihâd fî Sabîl al-Lâh secara Populis-Inklusif}

Persoalan mendasar yang sering dijadikan jargon dalam Islam adalah kalimat "al-Islâm shâlih li kull zamân wa makân". Dengan slogan ini, Islam memberikan afirmasi melalui seperangkat aturan dan norma yang terdokumentasi dalam al-Qur'an dan hadis, serta sumber-sumber hukum lainnya. Berkaitan dengan konsep fì sabîl al-Lâh dalam kelompok penerima zakat (al-ashnâf al-tsamaniyyah) tidak harus memaknainya secara rigid pada dalam

${ }^{24}$ Ibid., 334. 
konteks peperangan secara fisik an sich dengan membawa senjata untuk membunuh dan menghancurkan musuh Islam. Padahal kalau kembali kepada tujuan dari jihad, yakni untuk li i'lâ'i kalimât al-Islâm wa al-muslimîn (untuk meninggikan syi'ar Islam dan umat Islam), maka hal tersebut dapat dilakukan dengan pendekatan yang lebih populis-inklusif, yakni melalui dakwah $b i$ al-lisân maupun bi al-bâl (dalam pengertian sikap dan perilaku).

Dalam catatan sejarah, Nabi Muhammad saw. telah banyak mencontohkan dakwah dengan menggunakan cara-cara dialog, perdamaian tanpa harus mengangkat senjata (perang). Kâdim alSadr, Guru Besar Ilmu Ekonomi Sahid Bahesti University Teheran, Iran, menjelaskan bahwa Rasulullah melakukan berbagai macam cara untuk mengembangkan dakwah Islam, antara lain dengan menggunakan para penyair dan sastrawan untuk menyebarkan ajaran ajaran Islam. ${ }^{25}$ Selain dalam bentuk puisi dan orasi, media diplomasi juga dilakukan Rasulullah dalam menyiarkan Islam. Al-Sadr mengungkapkan secara cermat:

"Selama memimpin kaum muslimin, Rasulullah mengirim banyak sahabat ke berbagai negara untuk mengajak pemimpin serta masyarakatnya menerima Islam. Sebagai contoh, Rasulullah pernah mengirimkan tujuh puluh pemuda Anshâr untuk berdakwah kepada penduduk Najd, atas permintaan salah seorang dari mereka, ketika terjadi tragedi Bir Ma'unah. Demikian juga pada suatu hari di bulan Muharram tahun ke-7 setelah hijrah, Rasulullah mengirimkan beberapa utusan yang membawa surat Rasulullah ke enam negara untuk mengajak pemimpin dan penduduk negara itu kepada Islam. Jumlah duta Rasulullah itu seluruhnya 26 orang. Mereka selalu berhasil dalam menjalankan misi kecuali mengislamkan Kaisar Byzantium, Raja Persia beserta dua atau tiga orang. Petugas-petugas itu berangkat ke tempat tujuan dakwah dengan biaya sendiri, terkadang dibiayai Bayt al-Mâl. Pada tahun-tahun setelah hijrah berikutnya, ketika dana Bayt al-Mâl semakin banyak dan perjalanan yang harus ditempuh semakin jauh, biaya

${ }^{25}$ Kadim al-Sadr, "Kebijakan Fiskal pada Awal Pemerintahan Islam", dalam Adiwarman A. Karim, Sejarah Pemikiran Ekonomi Islam (Jakarta: IIIT, 2001), 98 . 
perjalanan serta gaji para utusan diambil dari dana Bayt al-Mâl' ${ }^{26}$

Dengan demikian, salah satu pengeluaran yang dibiayai dari Bayt al-Mâl-yang salah satu sumber dananya dari zakat-adalah dakwah dalam rangka menyebarkan ajaran Islam. Penyebaran Islam tersebut, sebagaimana dicontohkan oleh Rasulullah sendiri, tidak selalu dengan cara peperangan fisik. Pemaknaan jihad secara populis-inklusif ini, sesuai dengan konteks modern sekarang, karena seringkali jihad dengan mengangkat senjata menuai hasil yang tidak diinginkan, disebabkan beberapa hal: pertama, umat Islam secara umum sedang mengalami degradasi ilmu pengetahuan dan teknologi (IPTEK). Hal ini memberikan nilai tawar umat Islam (negara-negara muslim) menjadi sangat lemah, di mana negara-negara yang mayoritas penduduknya muslim menjadi konsumen utama berbagai jenis persenjataan dari negara-negara Barat. Kedua, negara-negara muslim kurang memiliki rasa persatuan yang kuat, sehingga mudah diperalat oleh negara-negara Barat. Ketiga, negara-negara muslim atau negara dengan penduduk mayoritas muslim masih berada dalam garis kemiskinan, sekalipun sumber daya alamnya kaya, misalnya Indonesia.

Jadi, makna jihad dalam al-ashnâf al-tsamâniyyah memiliki dua makna; makna sempit (tekstual) dan makna luas (kontekstual). Menurut 'Abd al-Lâh al-Muslih dan Shalah al-Shâwî, para ulama berbeda pendapat tentang dakwah Islam disebabkan perbedaan pendapat tentang alokasi harta fî sabîl al-Lâh. Ada sebagian ulama yang mengatakan bahwa fî sabîl al-Lâh itu, khusus bagi orangorang yang sukarela berperang atau berjihad; ada yang mengatakan memasukkan haji sebagai amalan fî sabîl al-Lâh; ada juga yang memperluas pemahaman tentang fî̀ sabîl al-Lâh sehingga berbagai usaha dakwah bahkan usaha amal kebajikan secara umum dikategorikan fî sabîl al-Lâh. ${ }^{27}$

26Ibid., 98-9.

27al-Musliḥ dan al-Shâwî, Mấ Lâ .., 478. 
Lembaga Kajian Fiqh yang termasuk dalam Râbithah 'Alâm al- Islâmî pada pertemuan kedua di Mekkah tahun $1405 \mathrm{H}$ mendiskusikan tentang salah satu alokasi zakat yang delapan yang tersebut dalam ayat, yakni fî̀ sabîl al-Lâh hanya berlaku untuk para mujâhidîn atau jalan Allah secara umum, yang meliputi segala sisi amal kebajikan berupa fasilitas untuk kepentingan umum seperti pembangunan masjid, benteng, jembatan ataupun dana untuk belajar mengajar, pengiriman tenaga dakwah dan sejenisnya.

Dalam hal ini ulama berbeda pendapat: pertama, pendapat yang "diamini" mayoritas ulama bahwa pengertian fî sabîl al-Lâh hanya untuk para mujahid. Kedua, fì sabîl al-Lâh bermakna kompleks, meliputi segala kebajikan, penyediaan berbagai fasilitas umum bagi kaum muslimin, seperti mendirikan dan melakukan pemeliharaan atas masjid, dan membangun berbagai fasilitas umum yang berguna bagi kepentingan agama dan kaum muslimin.

Setelah bertukar pikiran, mereka memutuskan bahwa: pendapat pertama yang dianut oleh mayoritas ulama memiliki kekeliruan secara teoritis bila memperhatikan sebagian ayat alQur'an, misalnya firman Allah dalam Qs. al-Baqarah (2): 262:

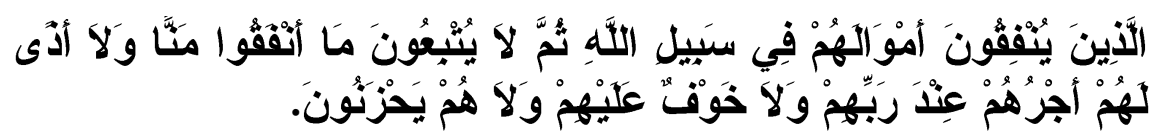

Artinya: "Orang-orang yang menafkahkan hartanya di jalan Allah, kemudian mereka tidak mengiringi apa yang dinafkahkannya itu dengan menyebut-nyebut pemberiannya dan tidak menyakiti (perasaan si penerima), mereka memperoleh pahala di sisi Tuhan mereka. Tidak ada kekhawatiran terhadap mereka dan mere tidak pula bersedih hati". 28

Kedua, tujuan jihad dengan senjata adalah memperhatikan kalimah al-Lâh dan menegakkan agama Allah. Selain dengan

${ }^{28}$ Qs. al-Baqarah (2): 262. 
perang, jihad itu juga dapat dilakukan dengan dakwah mengajak ke jalan Allah dan menyebarkan agama-Nya, melakukan pembinaan tenaga dakwah dan menyokong pengirimannya serta membantu mereka memenuhi kepentingan mereka. Hal ini berdasarkan sabda Nabi Muhammad saw.

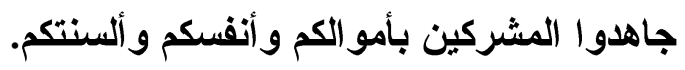

Artinya: "Berjihâdlah melawan orang-orang musyrik dengan harta, jiwa dan lisan kalian". ${ }^{29}$

Jika kita melihat bahwa Islam diperangi oleh kaum atheis, Yahudi, dan Nasrani melalui perang pemikiran dan akidah dengan dukungan dana yang kuat, maka seharusnya kaum muslimin menghadapi mereka dengan hal yang sama. Di berbagai negara Islam telah memiliki kementerian khusus untuk memberikan sokongan finansial untuk peperangan. Sementara jihad di bidang dakwah belum memiliki anggaran tersendiri. Atas dasar itu, dakwah segala aktivitasnya yang berkaitan dengannya termasuk makna fî sabîl al-Lâh dalam ayat al-Qur'an tersebut. ${ }^{30}$

Dalam sejarah perjuangan bangsa Indonesia menentang penjajahan, zakat merupakan sumber dana perjuangan. Hazairin pernah mengatakan dalam ceramahnya di Salatiga tanggal 16 Desember 1950 bahwa pengertian zakat seperti yang terdapat dalam al-Qur'an besar manfaatnya jika dipahami secara seksama. Cara pelaksanaannya memang perlu perubahan sehingga memenuhi keperluan bangsa Indonesia masa kini. Misalnya, jika diadakan bank zakat sebagai tempat pengumpulan dana jika tidak ada lagi yang menerima (mustabiq) manfaatnya akan besar sekali. ${ }^{31}$ Dalam konteks ini, M. Dawam Rahardjo sangat setuju dengan gagasan mengembangkan fiqh baru di bidang zakat.

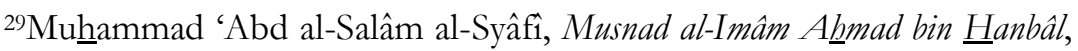
jilid III (Beirut: Dâr al-'Ilmiyyah, 1993), 152 dan 205. al-Shan'ânî, Subul ..., 76.

${ }^{30}$ al-Muslih dan al-Shâwî, Mâ Lâ..., 478-81.

${ }^{31} \mathrm{Ali}$, Sistem ..., 36 
Alasannya, karena figh zakat yang konvensional nampaknya sudah kurang memadai untuk menjawab persoalan-persoalan masyarakat masa kini. Struktur dan sistem ekonomi telah berubah yang diikuti dengan perubahan struktur sosial. ${ }^{32}$

Dengan semangat fikih baru dalam bidang zakat, Ali menguraikan pentingnya memperluas makna barang yang wajib dizakati. Sementara, dalam masalah penerima zakat (al-ashnâf altsamâniah), salah satunya ashnâf ketujuh, yakni fi sabîl al-Lâh dimasukkan segala keperluan peribadatan, pendidikan, dakwah, penelitian, penerbitan buku-buku, dan majalah ilmiah. ${ }^{33}$

\section{Catatan Akhir}

Masalah mustabiq al-zakât ini, para ulama klasik dan modern masing-masing ada yang memaknai dengan tekstual dan

${ }^{32}$ Masa lalu, peranan sektor pertanian sangat menonjol, sekarang telah menurun seiring menonjolnya peranan sektor industri dan jasa. Apabila fiqh zakat baru tidak dikembangkan, maka esensi tujuan zakat tidak akan berhasil, bahkan ketidakadilan akan terjadi. Misalnya, hanya golongan petani dan pedagang saja yang terkena kewajiban zakat padahal kedudukan ekonomis golongan petani makin lemah. Lihat M. Dawam Rahardjo, Islam dan Transformasi Sosial-Ekonomi (Jakarta: LSAF, 1999), 512-13.

${ }^{33}$ Dalam masalah sumber zakat, untuk sektor penghasilan harus disebutkan jenis barang yang bernilai ekonomis, penghasilan tetap dan tidak tetap; di sektor pertanian, disebutkan secara jelas jenis pertaniannya, bukan saja yang dapat mengenyangkan tetapi juga dapat dikembangkan, termasuk juga dalam sektor peternakan. Dalam konteks moneter/uang, selain emas dan perak dimasukkan juga semua alat pembayaran dan kertas berharga. Selain ashnâf fì sabil al-Lâh, dalam al-ashnâf al-tsamâniyyah perlu dikembangkan dimasukkan juga biaya penyantunan orang miskin di lembaga sosial dan bantuan modal bagi fakir-miskin. Dalam pengertian 'âmil harus dimasukkan juga biaya administrasi, personal dan aktivitasnya. Untuk mu'allaf, harus disiapkan juga untuk biaya dakwah Islamiyah. Pada kata ghârim, harus dimasukkan juga orang atau lembaga yang pailit karena pelaksanaan kegiatan yang baik dan sah menurut hukum Islam. Untuk ibn al-sabîl dimasukkan juga usaha guna membantu perjalanan seseorang yang kehabisan biaya, beasiswa, dan biaya ilmiah lainnya. Lihat Ali, Sistem...,57 dan 68. 
kontekstual, yakni peperangan mengangkat senjata dan dakwah Islamiyah. Pemaknaan kata fi sabîl al-Lâh secara kaku hanya kepada orang yang ikut dalam peperangan (ghuzzât) atau yang sering dipahami dengan istilah jïhâd fi sabîl al-Lâh, tidak dianggap menyelesaikan masalah, bahkan pemaknaan secara khusus (ekslusif) seperti itu terbukti telah menyalahi teoritisasi jihâd $f i$ sabîl al-Lâh itu sendiri, paling tidak dalam makna substansialnya.

Dengan dasar mashâlih al-ummat, pemaknaan secara umum (inklusif) kepada segala perbuatan yang baik dalam kerangka menegakkan syi'ar Islam dapat diterima dalam khazanah pemikiran ulama klasik dan modern. Apalagi setelah melihat kondisi modern sekarang, di mana segala gerak gerik kita dalam menegakkan syi'ar Islam sangat memerlukan biaya. Di samping itu, perjuangan dengan dialog dan dakwah Islamiyah dianggap lebih populis-inklusif dan lebih memiliki prospek yang jelas di balik keterbatasan umat Islam dari segala sisi, seperti degradasi IPTEK, kurangnya persatuan, kemiskinan, dan keterbelakangan.

Dalam rangka mengangkat syi'ar umat Islam dengan cara yang lebih bermartabat dan lebih mungkin mencapai target dan sasaran yang diinginkan, pemaknaan jỉhâd fì sabîl al-Lâh secara umum kepada semua kemaslahatan dakwah Islamiyah merupakan pilihan yang tepat dalam kerangka menegaskan jargon "Islam shâlih li kull zamân", al-Islâm a'lâ wa lâ yu'lâ 'alaih" dan "Islâm rabmah li al-âlamîn".

\section{Daftar Pustaka}

'Abd Allâh al-Muslih dan Shalah al-Shâwî, Mâ Lâ Yasa' al-Tâjir Jabluh, ter. Abu Umar Basyir (Jakarta: Darul Haq, 2004).

'Abd Rahmân Maḩmûd, Al-Nafakhât al-Shamâdiyyah (Mesir: alMadani, tt.).

Aḥmad Mushthafâ Al-Marâghî, Tafsîr Al-Marâghî (Mesir:

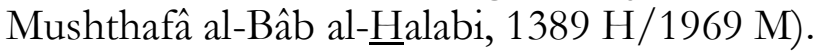


Ahmad Warson Al-Munawwir, Al-Munawwir: Kamus Arab Indonesia (Yogyakarta: Pondok Pesantren Krapyak, 1984).

Al-Bukhârî, Sabîh al-Bukhârî (Beirut: Dâr al-Kutub al-'Ilmiyyah, 1992).

Al-Shan'ânî, Subul al-Salâm (Beirut: Dâr al-Kutub al-'Ilmiyyah, 1988).

Jalâl al-Dîn Al-Suyûthî, Sunan al-Nasầî (Beirut: Dâr al-Ma'rifah, tt.).

M. Dawam Rahardjo, "Zakat dan Pengembangan Swadaya Umat Islam" dalam Islam dan Transformasi Sosial-Ekonomi (Yogyakarta: Pustaka Pelajar, 1999).

Masyfuk Zuhdi, "Sistem Zakat dan Dampaknya terhadap Pemerataan Pendapatan Masyarakat dan Peningkatan Kesejahteraan Masyarakat" dalam Masail Fiqbiyyah: Kapita Selekta Hukum Islam (Jakarta: Haji Masagung, 1994).

Mohammad Daud Ali, Sistem Ekonomi Islam, Zakat dan Wakaf (Jakarta: UI-Press, 1998).

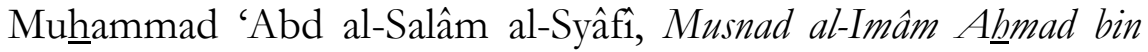
Hanbâl (Beirut: Dâr al-Ilmiyyah, 1993).

Muhammad 'Alî al-Sâyis, Tafsîr Âyât al-A $\underline{\text { hkâm }}$ (Mesir: Mathba'ah Muhammad Ali Shabih, tt.).

Muhammad al-Mahsyat, Bughyah al-Mustarsyidîn (t.k.: Mahfûzhah Li al-Nasyrî, tt.).

Muhammad Jamâl al-Dîn al-Qâsimî, Mabâsin al-Ta'wil (Beirut: Dâr Ihyâ' al-Kutub al-'Arabiyyah, 1376 H/1957 M).

Q. Shaleh, dkk., Ayat-Ayat Hukum: Tafsir dan Uraian PerintahPerintah dalam Al-Qur'an (Bandung: Diponegoro, 1976).

Sayyid Sabiq, Fiqh Sunnah (Libanon: Dâr Fikr, 1403H/1983M).

Wahbah al-Zuhailî, al-Figh al-Islâmî wa Adillatuh (Damsyik: Dâr al-Fikr, 1989).

Zainuddin Bin Abdul Aziz Al-Malibariy, Fath al-Mu'în, ter. M. Aliy As'ad (Kudus: Menara Kudus, 1979). 